\title{
FAKTOR PSIKOLOGIS DAN FAKTOR ORGANISASI BERPENGARUH TERHADAP KINERJA KARYAWAN PADA PT. BPR X
}

\author{
Kadek Selvina Devi ${ }^{1}$, Kadek Rai Suwena² \\ Jurusan Pendidikan Ekonomi \\ Universitas Pendidikan Ganesha \\ Singaraja, Indonesia \\ e-mail: selvina_devi@yahoo.co.id ${ }^{1}$,kadek_suwena@yahoo.co.id²
}

\begin{abstract}
Abstrak
Tujuan penelitian ini adalah untuk mengetahui pengaruh faktor psikologis dan faktor organisasi secara parsial dan simultan terhadap kinerja karyawan pada PT. BPR X. Jenis penelitian ini adalah penelitian kuantitatif dengan desain penelitian kausal. Populasi penelitian ini adalah seluruh karyawan PT. BPR X. Sampel penelitian ini adalah karyawan PT. BPR X sebanyak 34 orang. Pengumpulan data menggunakan kuesioner dianalisis menggunakan analisis regresi linier berganda berbantuan program SPSS 25.0 for Windows. Hasil penelitian menunjukkan bahwa ada pengaruh faktor psikologis terhadap kinerja karyawan, yang ditunjukkan dengan nilai probabilitas uji t 0,000 yang lebih kecil dari $\alpha=0,05$, ada pengaruh faktor organisasi terhadap kinerja karyawan, yang ditunjukkan dengan nilai probabilitas uji t 0,000 yang lebih kecil dari $\alpha=0,05$, dan ada pengaruh faktor psikologis dan faktor organisasi terhadap kinerja karyawan, yang ditunjukkan dengan nilai probabilitas uji $F$ 0,000 yang lebih kecil dari $\alpha=0,05$.
\end{abstract}

Kata kunci: faktor psikologis, faktor organisasi, kinerja karyawan.

\begin{abstract}
The purpose of this research was to determine the effect of psychological factors and organizational factors partially and simultaneously on employee performance at PT. BPR X. This type of research was quantitative research with causal research design. The population of this research were all employees of PT. BPR X. The sample of this research were employees of PT. BPR X as much as 34 people. Data collection used questionnaire analyzed using multiple linear regression analysis supported by SPSS 25.0 for Windows program. The result of the research shows that there was effect of psychological factor on employee performance, which was indicated by $t$ test probability value smaller than $\alpha=$ 0.05 , there was effect of organizational factor on employee performance, which was indicated by $t$ test probability value smaller than $\alpha=0.05$, and there were effect of psychological factor and organizational factor to employee performance, which was indicated by $F$ test probability value smaller than $\alpha=0.05$.
\end{abstract}

Keywords: psychological factors, organizational factors, employee performance.

\section{PENDAHULUAN}

Pembangunan nasional merupakan upaya berkesinambungan dalam rangka mewujudkan masyarakat Indonesia yang adil dan makmur. Pembangunan dilaksanakan dengan menggunakan instrumen-instrumen lembaga keuangan. Salah satu dari lembaga keuangan itu adalah bank. Kondisi perbankan dewasa ini semakin berkembang dan menunjukkan tingkat persaingan yang cukup ketat. Hal ini menjadi tantangan bagi BPR terutama

Kadek Selvina Devi I Page 24 dari 51 
menghadapi gempuran bank-bank umum yang sudah masuk wilayah mikro dengan tawaran suku bunga pinjaman lebih rendah dan fasilitas simpanan beragam. Padahal keberadaan BPR dirasa membantu perekonomian masyarakat secara mikro, khususnya bagi mereka yang memiliki usaha atau industri rumahan. Penyaluran kredit di BPR dirasa cukup membantu ekonomi masyarakat dan mampu menggerakan sektor perekonomian rakyat.

Berkembangnya jasa perbankan dengan tawaran suku bunga pinjaman rendah dan fasilitas simpanan beragam menuntut pihak pengusaha bank menyusun kebijakan untuk menghadapi persaingan yang ada. Kemampuan dan keunggulan dalam bersaing sangat diperlukan BPR untuk menghadapi persaingan yang cukup ketat tersebut. Salah satu usaha untuk menghadapi persaingan tersebut adalah meningkatkan kinerja karyawan. Hal ini dipertegas oleh pendapat Wibowo (2012) bahwa peningkatan kinerja karyawan diharapkan dapat mendukung tercapainya tujuan organisasi dan dapat menjaga kelangsungan hidup perusahaan.

Pada dasarnya setiap perusahaan menginginkan dan menuntut agar seluruh karyawan selalu menyelesaikan pekerjaannya dengan sebaik mungkin. Untuk meningkatkan kinerja karyawan, perusahaan harus memperhatikan faktorfaktor yang mempengaruhi kinerja. Menurut Gibson et al. (2012), faktor yang berpengaruh terhadap kinerja adalah faktor psikologis dan faktor organisasi. Faktor psikologis yang mempengaruhi kinerja adalah persepsi, sikap, nilai, kepuasan kerja, dan kepribadian, sedangkan faktor organisasi yang mempengaruhi kinerja, yaitu desain pekerjaan dan desain organisasi.

Menurut Gibson et al. (2012), faktor psikologis adalah sesuatu yang harus diamati pimpinan pada karyawan karena apa yang terjadi di dalam diri karyawan dapat dengan mudah ditutupi sehingga dapat memberikan informasi yang berarti untuk memecahkan perilaku dan masalah kinerja karyawan. Faktor psikologis adalah faktor yang berasal dari dalam individu karyawan terkait dengan kondisi kejiwaan dan mental karyawan yang dapat mempengaruhi kuantitas dan kualitas perolehan kinerja karyawan. Faktor psikologis harus diamati oleh pimpinan sehingga dapat memberikan informasi untuk memecahkan perilaku dan masalah kinerja karyawan.

Menurut Gibson et al. (2012), faktor organisasi adalah faktor yang berkaitan dengan pola formal dari aktivitas dan hubungan timbal balik antara berbagai subunit pada suatu organisasi. Faktor organisasi adalah faktor organisasi yang berkaitan dengan kerangka hubungan berstruktur, yang menunjukkan wewenang, tanggung jawab, dan pembagian kerja yang sangat menunjang bagi karyawan dalam mencapai prestasi kerja. Faktor organisasi berkaitan dengan uraian jabatan yang jelas, target kerja yang menantang, pola komunikasi kerja efektif, hubungan kerja harmonis, iklim kerja respek dan dinamis, peluang berkarier dan fasilitas kerja yang memadai.

PT. BPR $X$ merupakan salah satu salah satu bank yang dikenal melayani golongan masyarakat pengusaha mikro, kecil, dan menengah di Kabupaten Buleleng. PT. BPR $X$ berlokasi di Jalan Raya Kubutambahan, Kabupaten Buleleng, Provinsi Bali. PT. BPR $X$ meraih penghargaan Best BPR Award pada tahun 2017 untuk Aset 100-150 Milyar (Prayogo, 2017). Penghargaan yang diraih tidak menjamin PT. BPR $X$ tidak mengalami masalah dalam manajemen perusahaan. Permasalahan yang muncul pada PT. BPR $X$, yaitu berkaitan dengan rendahnya kinerja karyawan dalam menjalankan tugas dan fungsinya. Hal ini didasarkan pada hasil wawancara saat dilakukan penelitian awal dengan Kabid Operasional yang menyatakan bahwa dilihat fenomenafenomena yang terjadi antara lain terlihat beberapa karyawan yang bekerja hanya kalau ada tugas dari pimpinan, mereka tidak secara mandiri atau secara kreatif menyelesaikan pekerjaan dengan baik dan cepat, masih adanya karyawan yang bermalas-malasan pada waktu jam kerja, dan kurangnya kepedulian karyawan

Kadek Selvina Devi I Page 25 dari 51 
terhadap tugas-tugas yang dibebankan sehingga karyawan tidak menikmati pekerjaan yang dimilikinya. Seperti adanya ketidakdisiplinan karyawan pada saat masuk kerja yang datang terlambat dari aturan yang sudah ditetapkan yaitu pukul 08.00 wita bahkan pulang terlalu cepat dari peraturan yang sudah ditetapkan pukul 17.00 wita, istirahat kerja yang diberikan perusahaan juga masih sering dilanggar dengan kedatangan karyawan ke kantor lebih dari yang ditetapkan yaitu pukul 12.00 sampai 13.00 wita.

Jika permasalahan kinerja karyawan ini tidak diberikan solusi, maka motivasi karyawan akan semakin berkurang dan karyawan menjadi tidak disiplin dengan peraturan yang sudah ditetapkan, sehingga hal tersebut dapat menyebabkan terhambatnya pencapaian tujuan perusahaan. Berdasarkan uraian tersebut, maka dipandang perlu untuk menguji faktor psikologis dan organisasi terhadap kinerja karyawan PT. BPR X.

\section{METODE}

Jenis penelitian ini termasuk penelitian kuantitatif dengan desain penelitian kausal. Desain penelitian kausal adalah hubungan yang bersifat sebab akibat, variabel bebas merupakan variabel yang mempengaruhi dan variabel terikat merupakan variabel yang dipengaruhi. Adapun variabel bebas yang digunakan dalam penelitian ini adalah faktor psikologis dan faktor organisasi, sedangkan variabel terikat yang digunakan dalam penelitian ini adalah kinerja karyawan. Hasil yang diharapkan dapat menjelaskan mengenai pengaruh faktor psikologis dan faktor organisasi terhadap kinerja karyawan.

Penelitian ini dilakukan di PT. BPR X. Populasi adalah wilayah generalisasi yang terdiri dari obyek/subjek yang mempunyai kualitas dan karakteristik tertentu yang ditetapkan oleh peneliti untuk dipelajari dan kemudian ditarik kesimpulannya (Sugiyono, 2011). Populasi pada penelitian ini adalah seluruh karyawan PT. BPR X sebanyak 34 orang. Sampel adalah bagian dari jumlah dan karakteristik yang dimiliki oleh populasi (Sugiyono, 2011). Apabila populasi kurang dari 100 orang, maka sebaiknya semua dijadikan sebagai sasaran penelitian. Oleh karena itu, penelitian ini merupakan penelitian populasi atau penelitian sampel jenuh, yang artinya semua populasi dijadikan sebagai sampel penelitian. Populasi pada penelitian ini adalah 34 orang karyawan sehingga sampel dari penelitian ini juga berjumlah 34 orang karyawan.

Jenis data yang digunakan dalam penelitian ini adalah data kuantitatif, yaitu data yang dapat dihitung. Dalam penelitian ini yang termasuk dalam data kuantitatif adalah data hasil jawaban kuesioner mengenai faktor psikologis, faktor organisasi, dan kinerja karyawan. Sumber data yang digunakan adalah data primer. Data dikumpulkan secara langsung dari responden yang diperoleh dengan cara memberikan daftar pertanyaan yang berupa kuesioner mengenai faktor psikologis, faktor organisasi, dan kinerja karyawan pada PT. BPR X. Metode pengumpulan data yang digunakan dalam penelitian ini adalah kuesioner. Kuesioner merupakan suatu teknik pengumpulan data dalam penelitian dengan menggunakan angket yang berisi daftar pertanyaan kepada responden. Angket tersebut diberikan kepada para responden dan kemudian diharapkan setiap masing-masing responden akan mengisinya dengan pendapat dan persepsi setiap individu responden itu sendiri.

Angket diberikan langsung kepada responden, kemudian responden memilih salah satu dari alternatif jawaban yang telah tersedia. Kuesioner ditunjukan kepada atasan dan karyawan PT. BPR $X$ yang bertujuan untuk mengetahui pengaruh faktor psikologis dan faktor organisasi terhadap kinerja karyawan. Instrumen penelitian digunakan berdasarkan konsep dasar dari teori yang mendasari dari variabel-variabel penelitian. Instrumen dalam penelitian ini terdiri dari pertanyaanpertanyaan dikembangkan dari indikator dengan masalah yang diteliti. Berdasarkan pada indikator yang terdapat didalam jabaran variabel, maka dapat disusun dan dikembangkan menjadi instrumen penelitian yang berupa kuesioner atau angket. Skala 
pengukuran yang digunakan adalah skala Likert dengan lima alternatif jawaban. Variabel dalam penelitian yang telah ditetapkan akan dijabarkan menjadi indikator, dan dari indikator ini kemudian dijabarkan sebagai titik tolak untuk menyusun item intrumen yang kemudian diubah dalam beberapa pertanyaan yang selanjutnya dijawab oleh responden.

Kuesioner sebagai instrumen pengumpulan data terlebih dahulu harus diuji tingkat validitas dan reliabilitasnya. Untuk menguji tingkat validitas dan reliabilitas instrumen penelitian akan diujikan kepada 30 responden. Uji validitas digunakan untuk mengukur valid tidaknya suatu kuesioner. Kuisioner dikatakan valid apabila kuisioner mampu untuk mengungkapkan dengan pasti apa yang akan diteliti. Pengujian validitas dalam penelitian ini dilakukan dengan menggunakan korelasi Product Moment yang terdapat dalam program SPSS 25.0 for Windows. Suatu pertanyaan dikatakan valid jika $r_{\text {hitung }}>r_{\text {tabel }}$ dan kuisioner dikatakan tidak valid apabila $r_{\text {hitung }}<r_{\text {tabel }}$. Reliabilitas menunjuk pada satu pengertian bahwa suatu instrumen cukup dapat dipercaya untuk digunakan sebagai alat pengumpulan data karena instrumen tersebut sudah baik. Dalam penelitian ini pengujian reliabilitas instrumen dilakukan dengan membandingkan nilai Cronbach Alpha yang diperoleh dari SPSS 25.0 for Windows dengan batas nilai Crombach Alpha untuk mengukur instrumen yang reliabel. Pengujian statistik dengan menggunakan teknik statistik Cronbach Alpha instrumen dikatakan reliabel untuk mengukur variabel apabila memiliki nilai Cronbach Alpha lebih > 0,60. Hasil uji validitas pada kuesioner faktor psikologis menunjukkan bahwa 25 item pernyataan dinyatakan valid dan 5 item pernyataan dinyatakan tidak valid. Hasil uji validitas pada kuesioner faktor organisasi menunjukkan bahwa 9 item pernyataan dinyatakan valid dan 3 item pernyataan dinyatakan tidak valid. Hasil uji validitas pada kuesioner kinerja karyawan menunjukkan bahwa seluruh 18 item pernyataan dinyatakan valid. Hasil uji reliabilitas menunjukan bahwa kuesioner faktor psikologis, faktor organisasi, dan kinerja karyawan memiliki Alpha Cronbach lebih besar dari 0,60 sehingga kuesioner dinyatakan reliabel.

Sesuai dengan rumusan masalah, tujuan penelitian, dan hipotesis penelitian, data dianalisis untuk mengetahui pengaruh faktor psikologis dan faktor organisasi terhadap terhadap kinerja karyawan PT. Bank Perkreditan Rakyat X. Data yang didapat dari kuesioner adalah data ordinal. Agar dapat menguji hipotesis, data tersebut diubah menjadi data interval melalui Method of Successive Interval dengan bantuan program Microsoft Office Excel 2007.

Analisis data dilakukan untuk menguji hipotesis yang diajukan, yaitu untuk mengetahui ada tidaknya hubungan antara variabel bebas $(X)$ dengan variabel terikat $(\mathrm{Y})$, sehingga analisis data yang digunakan dalam penelitian ini adalah analisis regresi linier berganda. Teknik analisis regresi linier berganda akan menguji hipotesis yang menyatakan ada pengaruh antara variabel bebas terhadap variabel terikat. Manfaat dari hasil analisis regresi adalah untuk membuat keputusan apakah naik dan menurunnya variabel terikat dapat dilakukan melalui peningkatan variabel bebas atau tidak. Analisis regresi digunakan untuk memprediksi seberapa jauh perubahan nilai variabel terikat, jika nilai variabel bebas dimanipulasi. Regresi linier berganda digunakan untuk mengetahui pengaruh antara dua variabel bebas atau lebih terhadap variabel terikat (Sugiyono, 2011). Berdasarkan hasil analisis regresi linier berganda dapat diketahui persamaan garis regresi sebagai berikut.

$Y=\alpha+\beta_{1} X_{1}+\beta_{2} X_{2}+\varepsilon$

Keterangan:

$\mathrm{Y}=$ kinerja karyawan

$\alpha=$ konstanta

$\beta=$ koefisien regresi

$\varepsilon=$ error term

$\mathrm{X}_{1}=$ faktor psikologis

$X_{2}=$ faktor organisasi

Pengujian hipotesis secara parsial menggunakan uji t. Uji t digunakan untuk 
menguji pengaruh variabel bebas secara parsial terhadap variabel terikat dengan menganggap variabel lain bersifat konstan (Ghozali, 2011). Pengujian ini dilakukan dengan cara membandingkan thitung dengan tabel. Adapun langkah-langkah pengujiannya, yaitu: perumusan hipotesis, menentukan tingkat signifikan ( $\alpha$ ) yaitu sebesar 5\%, menentukan kriteria penerimaan atau penolakan $\mathrm{H}_{0}$ dengan melihat nilai signifikan. Jika nilai signifikan < $5 \%$, maka $\mathrm{H}_{0}$ ditolak dan jika nilai signifikan $>5 \%$, maka $\mathrm{H}_{0}$ diterima, dan pengambilan keputusan.

Pengujian hipotesis secara simultan menggunakan uji F. Uji F digunakan untuk menguji pengaruh variabel bebas secara simultan terhadap variabel terikat (Ghozali, 2011). Pengujian ini dilakukan dengan cara membandingkan $F_{\text {hitung }}$ dengan $F_{\text {tabel- }}$ Adapun langkah-langkah pengujiannya, yaitu: perumusan hipotesis, menentukan tingkat signifikan $(\alpha)$ yaitu sebesar $5 \%$, menentukan kriteria penerimaan atau penolakan $\mathrm{H}_{0}$ dengan melihat nilai signifikan. Jika nilai signifikan $<5 \%$, maka
$\mathrm{H}_{0}$ ditolak dan jika nilai signifikan $>5 \%$, maka $\mathrm{H}_{0}$ diterima, dan pengambilan keputusan.

Besar pengaruh faktor psikologis dan faktor organisasi terhadap kinerja karyawan dapat diketahui dari koefisien determinasi. ( $R$ Square). Nilai $R$ Square yang kecil berarti kemampuan variabel-variabel bebas dalam menjelaskan variasi variabel terikat sangat terbatas. Nilai yang mendekati 1 (satu) berarti variabel-variabel bebas memberikan hampir semua informasi yang dibutuhkan untuk memprediksi variasi variabel terikat (Ghozali, 2011).

\section{HASIL DAN PEMBAHASAN}

Berdasarkan hasil analisis data menunjukkan bahwa pengaruh faktor psikologis terhadap kinerja karyawan pada PT. BPR $X$ dapat diketahui dengan menggunakan uji t. Perhitungan uji $t$ menggunakan bantuan program SPSS 25.0 for Windows dan pengujian hipotesis dilakukan pada taraf signifikansi $5 \%$. Hasil uji t dapat dilihat pada tabel 1.

Tabel 1. Hasil Uji t untuk Variabel Faktor Psikologis Terhadap Kinerja Karyawan

\begin{tabular}{llccccc}
\hline & \multirow{2}{*}{ Model } & \multicolumn{2}{c}{$\begin{array}{c}\text { Unstandardized } \\
\text { Coefficients }\end{array}$} & $\begin{array}{c}\text { Standardized } \\
\text { Coefficients } \\
\text { Beta }\end{array}$ & T & Sig. \\
& & B & Std. Error & & & \\
\hline 1 & (Constant) & $-34,836$ & 9,612 & & $-3,624$ & 0,001 \\
& Faktor psikologis & 0,997 & 0,146 & 0,656 & 6,841 & 0,000 \\
\hline
\end{tabular}

a. Dependent Variable: Kinerja karyawan

Berdasarkan tabel 1, diperoleh nilai thitung $_{\text {in }}=6,841>t_{\text {tabel }}=2,037$ dan $p$-value sebesar $0,000<\alpha=0,05$, maka keputusannya $\mathrm{H}_{0}$ ditolak. Jadi, terdapat pengaruh signifikan antara faktor psikologis terhadap kinerja karyawan PT. BPR X.

Berdasarkan hasil analisis data menunjukkan bahwa pengaruh faktor organisasi terhadap kinerja karyawan pada PT. BPR $X$ dapat diketahui dengan menggunakan uji t. Perhitungan uji $t$ menggunakan bantuan program SPSS 25.0 for Windows dan pengujian hipotesis dilakukan pada taraf signifikansi $5 \%$. Hasil uji t dapat dilihat pada tabel 2.

Tabel 2. Hasil Uji t untuk Variabel Faktor organisasi Terhadap Kinerja Karyawan

\begin{tabular}{llccccc}
\hline \multirow{2}{*}{ Model } & \multicolumn{2}{c}{$\begin{array}{c}\text { Unstandardized } \\
\text { Coefficients }\end{array}$} & $\begin{array}{c}\text { Standardized } \\
\text { Coefficients } \\
\text { Beta }\end{array}$ & T & Sig. \\
& & B & Std. Error & Beta & & \\
\hline 1 & (Constant) & $-34,836$ & 9,612 & & $-3,624$ & 0,001 \\
& Faktor organisasi & 0,590 & 0,149 & 0,381 & 3,969 & 0,000 \\
\hline
\end{tabular}


a. Dependent Variable: Kinerja karyawan

Berdasarkan tabel 2, diperoleh nilai $t_{\text {hitung }}=3,969>t_{\text {tabel }}=2,037$ dan $p$-value sebesar $0,000<\alpha=0,05$, maka keputusannya $\mathrm{H}_{0}$ ditolak. Jadi, terdapat pengaruh signifikan antara faktor organisasi terhadap kinerja karyawan PT. BPR X.

Pengaruh faktor psikologis dan faktor organisasi terhadap kinerja karyawan pada PT. BPR $X$ secara simultan diuji dengan menggunakan uji $F$. Perhitungan uji $F$ menggunakan bantuan program SPSS 25.0 for Windows dan pengujian hipotesis dilakukan pada taraf signifikansi $5 \%$. Hasil uji $\mathrm{F}$ dapat dilihat pada tabel 3.

Tabel 3. Hasil Uji F untuk Variabel Faktor Psikologis dan Faktor Organisasi

Terhadap Kinerja Karyawan

\begin{tabular}{llccccc}
\multicolumn{7}{c}{ ANOVA } \\
\hline \multirow{2}{*}{ Model } & Sum of & df & Mean & F & Sig. \\
\hline Regression & Squares & 858,487 & 2 & 429,243 & 46,383 & 0,000 \\
& Residual & 286,884 & 31 & 9,254 & & \\
& Total & 1145,370 & 33 & & & \\
\hline
\end{tabular}

a. Dependent Variable: Kinerja karyawan

b. Predictors: (Constant), Faktor psikologis, Faktor organisasi

Berdasarkan tabel 3, diperoleh nilai $F_{\text {hitung }}=46,383>F_{\text {tabel }}=3,32$ dengan nilai $p$ value sebesar $0,000<0,05$, maka keputusannya $\mathrm{H}_{0}$ ditolak. Jadi, terdapat pengaruh signifikan antara faktor psikologis dan faktor organisasi terhadap kinerja karyawan PT. BPR X.
Besar pengaruh faktor psikologis dan faktor organisasi terhadap kinerja karyawan pada PT. BPR $\mathrm{X}$ dapat diketahui dari koefisien determinasi, yang ditunjukkan dengan nilai $R$ Square. Hasil analisis koefisien determinasi dapat disajikan pada tabel 4.

Tabel 4. Hasil Analisis Koefisien Determinasi

\begin{tabular}{ccccc}
\hline Model & $\mathrm{R}$ & $\mathrm{R}$ Square & $\begin{array}{c}\text { Adjusted } \\
\mathrm{R} \text { Square }\end{array}$ & $\begin{array}{c}\text { Std. Error } \\
\text { of the Estimate }\end{array}$ \\
\hline 1 & 0,866 & 0,750 & 0,733 & 3,042 \\
\hline
\end{tabular}

a. Predictors: (Constant), Faktor psikologis, Faktor organisasi

Berdasarkan tabel 4, diketahui bahwa hasil perhitungan koefisien determinasi sebesar 0,750 . Hal ini menunjukkan bahwa $75,0 \%$ variabel kinerja karyawan pada PT. BPR $X$ dipengaruhi oleh variabel faktor psikologis dan faktor organisasi, sedangkan $25,0 \%$ dipengaruhi oleh faktor lain yang tidak termasuk dalam penelitian ini.
Berdasarkan hasil analisis regresi linier berganda, dapat diketahui persamaan garis regresi untuk mengetahui pengaruh faktor psikologis dan faktor organisasi terhadap kinerja karyawan pada PT. BPR X dengan menggunakan analisis koefisien beta. Hasil perhitungan konstanta dan koefisien beta dapat dilihat pada tabel 5 .

Tabel 5. Hasil Analisis Koefisien Beta

\begin{tabular}{|c|c|c|c|c|c|}
\hline \multirow[t]{2}{*}{ Model } & \multicolumn{2}{|c|}{$\begin{array}{c}\text { Unstandardized } \\
\text { Coefficients }\end{array}$} & \multirow{2}{*}{$\begin{array}{c}\text { Standardized } \\
\text { Coefficients } \\
\text { Beta }\end{array}$} & \multirow[t]{2}{*}{$\mathrm{T}$} & \multirow[t]{2}{*}{ Sig. } \\
\hline & B & Std. Error & & & \\
\hline 1 (Constant) & $-34,836$ & 9,612 & & $-3,624$ & 0,001 \\
\hline
\end{tabular}




\begin{tabular}{llllll} 
Faktor psikologis & 0,997 & 0,146 & 0,656 & 6,841 & 0,000 \\
Faktor organisasi & 0,590 & 0,149 & 0,381 & 3,969 & 0,000 \\
\hline
\end{tabular}

a. Dependent Variable: Kinerja karyawan

Berdasarkan perhitungan regresi linier berganda pada Tabel 5, maka didapat hasil persamaan regresi sebagai berikut.

$Y=-34,836+0,997 X_{1}+0,590 X_{2}$

Keterangan:

$\mathrm{Y}=$ kinerja karyawan

$\mathrm{X}_{1}=$ faktor psikologis

$\mathrm{X}_{2}=$ faktor organisasi

Berdasarkan model persamaan regresi yang terbentuk, dapat diinterpretasikan hasil bahwa konstanta sebesar -34,836 menunjukan jika variabel faktor psikologis $\left(X_{1}\right)$ dan faktor organisasi $\left(X_{2}\right)$ bernilai konstan atau nol, maka variabel kinerja karyawan $(Y)$ memiliki nilai negatif sebesar 34,836. Selanjutnya, variabel faktor psikologis $\left(X_{1}\right)$ memiliki koefisien positif sebesar 0,997 dan variabel faktor organisasi $\left(X_{2}\right)$ memiliki koefisien positif sebesar 0,590. Nilai koefisien regresi yang positif menunjukkan bahwa faktor psikologis $\left(X_{1}\right)$ dan faktor organisasi $\left(X_{2}\right)$ berpengaruh positif terhadap kinerja karyawan (Y). Hal ini menggambarkan bahwa peningkatan faktor psikologis $\left(X_{1}\right)$ dan faktor organisasi $\left(X_{2}\right)$ sebesar satu satuan akan dapat meningkatkan kinerja karyawan ( $\mathrm{Y}$ ) sebesar nilai koefisien beta masing-masing variabel bebas dikalikan dengan besar kenaikan yang terjadi. Misalnya, setiap terjadi kenaikan faktor psikologis $\left(X_{1}\right)$ sebesar satu satuan, maka akan meningkatkan kinerja karyawan (Y) sebesar 0,997 dan setiap terjadi kenaikan faktor organisasi $\left(X_{2}\right)$ sebesar satu satuan, maka akan meningkatkan kinerja karyawan (Y) sebesar 0,590. Hal ini menunjukkan bahwa semakin baik faktor psikologis dan faktor organisasi, maka semakin baik kinerja karyawan. Sebaliknya, semakin buruk faktor psikologis dan faktor organisasi, maka semakin rendah kinerja karyawan.

Hasil penelitian menunjukkan bahwa terdapat pengaruh yang siginifikan antara faktor psikologis dengan kinerja karyawan. Persamaan regresi punya arah koefisien positif sebesar 0,997. Pengaruh positif menunjukkan bahwa hubungan faktor psikologis dan kinerja karyawan adalah searah. Jika faktor psikologis yang dimiliki karyawan semakin baik, maka kinerja karyawan semakin baik. Faktor psikologis karyawan semakin baik ditunjukkan dengan semakin baiknya persepsi karyawan terhadap pekerjaan, memiliki sikap yang baik, memiliki kepuasan kerja, dan kepribadian yang baik. Kondisi riil yang terjadi di tempat penelitian berdasarkan hasil jawaban responden terhadap kuesioner menunjukkan bahwa semakin baiknya persepsi karyawan terhadap pekerjaan ditunjukkan dengan karyawan setuju bahwa pekerjaan yang dilaksanakan menuntut tanggung jawab lebih besar dan pekerjaan dilaksanakan selalu didukung penuh oleh pimpinan, karyawan memiliki sikap yang baik ditunjukkan dengan karyawan setuju bahwa ketika hasil pekerjaan tidak sesuai target dan dikenai sanksi dari atasan, karyawan tetap mengendalikan emosi serta selalu optimis bisa mengatasi permasalahan kerja, karyawan memiliki kepuasan kerja ditunjukkan dengan karyawan setuju bahwa gaji diterima sudah adil karena sesuai dengan beban kerja dan tanggung jawab kerja dan kesempatan promosi naik jabatan diberikan perusahaan sesuai dengan prestasi yang diraih karyawan, karyawan memiliki kepribadian yang baik ditunjukkan dengan karyawan setuju bahwa pekerjaan yang dilaksanakan menuntut karyawan untuk tekun bekerja dan memiliki empati dengan orang lain atau memahami orang lain ketika mengalami permasalahan. Hal tersebut akan mendukung kinerja karyawan semakin baik. Berdasarkan hasil penelitian, dapat diambil suatu kesimpulan bahwa faktor psikologis berpengaruh signifikan terhadap kinerja karyawan. Hasil penelitian ini didukung teori yang dikemukan oleh Gibson et al. (2012), yang menyatakan bahwa salah satu faktor yang berpengaruh terhadap kinerja adalah faktor psikologis. $\mathrm{Hal}$ ini sesuai dengan pendapat Baharuddin dan Wahyuni (2010) bahwa faktor psikologis adalah faktor rohaniah yang

Kadek Selvina Devi I Page 30 dari 51 
dapat mempengaruhi kuantitas dan kualitas perolehan kinerja karyawan. Pendapat tersebut menunjukkan bahwa faktor psikologis berpengaruh terhadap kinerja karyawan. Artinya, jika faktor psikologis yang dimiliki pegawai semakin baik, maka kinerja pegawai akan semakin meningkat. Hasil penelitian ini didukung oleh hasil penelitian terdahulu yang dilakukan oleh Ma'arif (2013), yang menemukan bahwa faktor psikologis yang mempengaruhi secara langsung kinerja karyawan.

Hasil penelitian menunjukkan bahwa terdapat pengaruh yang siginifikan antara faktor organisasi dengan kinerja karyawan. Persamaan regresi punya arah koefisien positif sebesar 0,590. Pengaruh positif menunjukkan bahwa hubungan faktor organisasi dan kinerja karyawan adalah searah. Jika faktor organisasi semakin baik, maka kinerja karyawan semakin baik. Faktor organisasi semakin baik ditunjukkan dengan semakin baiknya desain pekerjaan dan desain organisasi. Kondisi riil yang terjadi di tempat penelitian berdasarkan hasil jawaban responden terhadap kuesioner menunjukkan bahwa semakin baiknya desain pekerjaan ditunjukkan dengan karyawan setuju bahwa perusahaan selalu memberikan pekerjaan dengan standar kerja yang jelas, penempatan tugas karyawan sudah sesuai dengan tuntutan persyaratan pekerjaan, dan pembagian jadwal kerja yang diberikan perusahaan sudah fleksibel dan semakin baiknya desain organisasi ditunjukkan dengan karyawan setuju bahwa pembagian pekerjaan yang diberikan perusahaan sudah sesuai dengan struktur organisasi, pembagian divisi kerja yang diberikan perusahaan sesuai dengan tingkat pendidikan atau pelatihan yang telah dijalani karyawan, dan perusahaan mampu menciptakan keseimbangan antara tugas dan tanggung jawab dalam pembagian wewenang pekerjaan. Hal tersebut akan mendukung kinerja karyawan semakin baik. Berdasarkan hasil penelitian, dapat diambil suatu kesimpulan bahwa terdapat faktor organisasi berpengaruh signifikan terhadap kinerja karyawan. Hasil penelitian ini didukung teori yang dikemukan oleh Gibson et al. (2012), yang menyatakan bahwa salah satu faktor yang berpengaruh terhadap kinerja adalah faktor organisasi. Hal ini sesuai dengan pendapat Mangkunegara (2010) bahwa faktor organisasi adalah faktor lingkungan kerja yang sangat menunjang bagi individu dalam mencapai prestasi kerja. Pendapat tersebut menunjukkan bahwa faktor organisasi berpengaruh terhadap kinerja karyawan. Artinya, jika faktor organisasi yang dimiliki perusahaan semakin baik, maka kinerja karyawan akan semakin meningkat. Hasil penelitian ini didukung oleh hasil penelitian terdahulu yang dilakukan oleh Irawan (2015), yang menemukan bahwa faktor organisasi berpengaruh secara langsung terhadap kinerja Pegawai Negeri Sipil.

Hasil penelitian menunjukkan bahwa secara simultan terdapat pengaruh yang signifikan antara faktor psikologis dan faktor organisasi terhadap kinerja karyawan. Jika faktor psikologis dan faktor organisasi semakin baik, maka kinerja karyawan semakin baik. Karyawan yang tekun bekerja dan didukung penuh oleh pimpinan serta mendapatkan gaji yang layak dan kesempatan promosi naik jabatan dapat mengakibatkan kinerja karyawan makin baik. Selanjutnya, standar kerja yang jelas, pembagian pekerjaan sesuai dengan struktur organisasi, pembagian divisi kerja sesuai dengan tingkat pendidikan atau pelatihan yang telah dijalani karyawan dapat juga mengakibatkan makin baiknya kinerja karyawan. Berdasarkan hasil penelitian, dapat diambil suatu kesimpulan bahwa secara simultan terdapat pengaruh yang signifikan antara faktor psikologis dan faktor organisasi terhadap kinerja karyawan. Hasil penelitian ini didukung teori yang dikemukan oleh Gibson et al. (2012), yang menyatakan bahwa faktor yang berpengaruh terhadap kinerja adalah faktor psikologis dan faktor organisasi. Kinerja secara umum dipengaruhi faktor psikologis dan faktor organisasi. Pendapat tersebut menunjukkan bahwa faktor psikologis dan faktor organisasi berpengaruh terhadap kinerja karyawan. Hasil penelitian ini didukung oleh hasil penelitian terdahulu yang dilakukan oleh Siregar (2012), yang

Kadek Selvina Devi I Page 31 dari 51 
menemukan bahwa faktor psikologis dan organisasi (sumber daya dan imbalan) berpengaruh signifikan pada alpha 5\% terhadap kinerja pegawai.

\section{SIMPULAN DAN SARAN Simpulan}

Berdasarkan hasil analisis data dan pembahasan hasil penelitian maka dapat ditarik simpulan sebagai berikut. Pertama, ada pengaruh faktor psikologis terhadap kinerja karyawan pada PT. BPR $X$, yang ditunjukkan dengan koefisien regresi yang positif 0,997 dengan nilai $t_{\text {hitung }}=6,841>$ $t_{\text {tabel }}=2,037$ dan nilai probabilitas uji t 0,000 yang lebih kecil dari $\alpha=0,05$. Kedua, ada pengaruh faktor organisasi terhadap kinerja karyawan pada PT. BPR X, yang ditunjukkan dengan koefisien regresi yang positif 0,590 dengan nilai thitung $=3,969>$ $t_{\text {tabel }}=2,037$ dan nilai probabilitas uji t 0,000 yang lebih kecil dari $\alpha=0,05$. Ketiga, ada pengaruh faktor psikologis dan faktor organisasi terhdap kinerja karyawan pada PT. BPR $X$, yang ditunjukkan dengan nilai $F_{\text {hitung }}=46,383>F_{\text {tabel }}=3,32$ dan nilai probabilitas uji $F$ 0,000 yang lebih kecil dari $\alpha=0,05$.

\section{Saran}

Berdasarkan simpulan diatas, maka dapat dikemukakan beberapa saran sebagai berikut. Pertama, hasil penelitian factor psikologis dan faktor organisasi pada BPR X, menunjukkan variabel faktor organisasi besar pengaruhnya masih lemah terhadap kinerja karyawan, yang ditunjukkan dengan nilai kuadrat dari Standardized Coefficients Beta untuk faktor organisasi sebesar 0,145 sehingga besar pengaruhnya hanya $14,5 \%$ terhadap kinerja karyawan. Oleh karena itu, disarankan kepada pihak manajemen PT. BPR X untuk lebih memperhatikan kondisi faktor organisasi salah satunya meningkatkan kejelasan standar kerja karyawan, misalnya selama ini karyawan bekerja tidak mempunyai panduan kerja sehingga hasil yang diperoleh tidak maksimal. Untuk itu diperlukan adanya standar kerja karyawan yang jelas. Cara lainnya adalah membuat jadwal kerja yang fleksibel, misalnya selama ini waktu pulang kerja karyawan lebih lama dari waktu yang telah ditentukan, sehingga karyawan merasa tidak nyaman dengan jam kerja berlebih dan kinerjanya tidak maksimal. Untuk itu, diperlukan adanya jadwal kerja yang fleksibel. Cara selanjutnya adalah menyesuaikan pembagian pekerjaan dengan struktur organisasi, misalnya selama ini karyawan mendapatkan tugas tambahan yang tidak sesuai dengan jabatan pada struktur organisasi, sehingga tugas pokok karyawan hasilnya tidak maksimal. Untuk itu, diperlukan pembagian pekerjaan sesuai dengan jabatan pada struktur organisasi. Kedua, bagi peneliti selanjutnya yang tertarik untuk mengkaji aspek yang serupa mengenai pengaruh faktor psikologis dan faktor organisasi terhadap kinerja karyawan diharapkan untuk mengembangkan penelitian ini dengan menggunakan populasi dan sampel yang lebih luas, tidak hanya di PT. BPR $X$, tetapi juga di BPR lainnya agar hasil penelitian lebih teruji keandalannya.

\section{DAFTAR PUSTAKA}

Baharuddin dan Wahyuni, Esa Nur. 2010. Teori Belajar \& Pembelajaran. Yogyakarta: Ar-Ruzz Media.

Ghozali, Imam. 2011. Aplikasi Analisis Multivariate dengan Program SPSS. Semarang: Badan Penerbit Universitas Diponegoro.

Gibson, James L., Ivancevich, John M., Donnelly, James H., dan Konopaske, Robert. 2012. Organizations: Behavior, Structure, Processes. New York: McGraw-Hill.

Idrees, Muhammad Dawood, Maria Hafeez, dan Jung-Yong Kim. 2017. Workers' Age and the Impact of Psychological Factors on the Perception of Safety at Construction Sites. Sustainability Journal, 9(745), 1-15.

Irawan, Andi. 2015. Faktor-faktor yang Memengaruhi Kinerja Pegawai Negeri Sipil di Direktorat Jenderal Pendidikan Tinggi. Jurnal Aplikasi Bisnis dan Manajemen (JABM), 1(1), 55-64.

Kadek Selvina Devi I Page 32 dari 51 
Ma'arif, M. Syamsul. 2013. Faktor-faktor yang Mempengaruhi Kinerja Pegawai: Studi di Perusahaan Daerah Pasar Tohaga Kabupaten Bogor. Jurnal Aplikasi Manajemen, 11(2), 241-249.

Mangkunegara, A. A. Anwar Prabu. 2010. Evaluasi Kinerja SDM. Bandung: PT.Refika Aditama.

Parker, C. P., Baltes, B. B., Young, S. A., Huff, J. W., Altmann, R. A., Lacost, H. A., Roberts, J. E. 2003. Relationships Between Psychological Climate Perceptions and Work Outcomes: A Meta-Analytic Review. Journal of Organizational Behavior, 24, 389-416.

Prayogo, Hanggoro Setyo. 2017. Tersedia pada https://www.wartaekonomi. co.id /read139376/inilah-peraih-bestbpr-award-2017.html (diakses tanggal 20 Februari 2018).

Siregar, Henny Sahriani. 2012. Pengaruh Faktor Psikologis dan Organisasi Terhadap Kinerja Bidan Dalam Pelaksanaan Program Jaminan Persalinan di Kota Padangsidimpuan. Tesis tidak diterbitkan. Medan: Universitas Sumatra Utara.

Sugiyono. 2011. Statistika Untuk Penelitian. Bandung: Alfabeta.

Wibowo. 2012. Manajemen Kinerja. Jakarta: Raja Grafindo Persada. 